\title{
Correction to: Novel risk genes and mechanisms implicated by exome sequencing of 2572 individuals with pulmonary arterial hypertension
}

Na Zhu ${ }^{1,2+}$, Michael W. Pauciulo ${ }^{3,4+}$, Carrie L. Welch ${ }^{1 \dagger}$, Katie A. Lutz ${ }^{3}$, Anna W. Coleman ${ }^{3}$, Claudia Gonzaga-Jauregui ${ }^{5}$, Jiayao Wang ${ }^{1,2}$, Joseph M. Grimes ${ }^{1}$, Lisa J. Martin ${ }^{3,4}$, Hua He ${ }^{3}$, PAH Biobank Enrolling Centers' Investigators, Yufeng Shen ${ }^{2,6 \dagger}$, Wendy K. Chung ${ }^{1,7,8+}$ and William C. Nichols $s^{3,4^{* \dagger}}$

Correction to: Genome Med 11, 69 (2019) https://doi.org/10.1186/s13073-019-0685-z

Following publication of the original article [1], two errors were identified in the Results section.

1. The sentence currently reads:

"For IPAH, we observed significant associations for BMPR2 $(p=1.0 \mathrm{E}-7, \mathrm{FDR}=9.0 \mathrm{E}-04), \mathrm{KLK} 1(p=1.0 \mathrm{E}-7$, $\mathrm{FDR}=9.0 \mathrm{E}-04)$, and $\mathrm{GGCX}(p=5.0 \mathrm{E}-07, \mathrm{FDR}=0.002)$ (see Fig. 4).

The sentence should read

"For IPAH, we observed significant associations for BMPR2 $(p=1.0 \mathrm{E}-7, \mathrm{FDR}=9.0 \mathrm{E}-04), \mathrm{KLK} 1(p=1.0 \mathrm{E}-7$, $\mathrm{FDR}=9.0 \mathrm{E}-04)$, and GGCX $(p=1.9 \mathrm{E}-06, \mathrm{FDR}=0.013)$.

Further down in the text:

2. The sentence currently reads:

"Likewise, while the association signal for GDF2 fell below the cutoff ( $p=3.0 \mathrm{E}-07, \mathrm{FDR}=0.002)$, we clearly provide confirmation of this new PAH risk gene".

The sentence should read:

The original article can be found online at https://doi.org/10.1186/s13073019-0685-z.

* Correspondence: Bill.Nichols@cchmc.org

${ }^{+}$Na Zhu, Michael W. Pauciulo, Carrie L. Welch, Yufeng Shen, Wendy K. Chung and William C. Nichols contributed equally to this work.

${ }^{3}$ Division of Human Genetics, Cincinnati Children's Hospital Medical Center, 3333 Burnet Avenue MLC, Cincinnati, OH 7016, USA

${ }^{4}$ Department of Pediatrics, College of Medicine, University of Cincinnati, Cincinnati, $\mathrm{OH}$, USA

Full list of author information is available at the end of the article
"Likewise, while the association signal for GDF2 fell below the cutoff ( $p=3.2 \mathrm{E}-06, \mathrm{FDR}=0.016)$, we clearly provide confirmation of this new PAH risk gene".

The original article [1] has been corrected.

\section{Author details}

'Department of Pediatrics, Columbia University Medical Center, New York, NY, USA. ²Department of Systems Biology, Columbia University, New York, NY, USA. ${ }^{3}$ Division of Human Genetics, Cincinnati Children's Hospital Medical Center, 3333 Burnet Avenue MLC, Cincinnati, OH 7016, USA. ${ }^{4}$ Department of Pediatrics, College of Medicine, University of Cincinnati, Cincinnati, OH, USA. ${ }^{5}$ Regeneron Genetics Center, Regeneron Pharmaceuticals, Tarrytown, New York, NY, USA. ${ }^{6}$ Department of Biomedical Informatics, Columbia University, New York, NY, USA. ${ }^{7}$ Herbert Irving Comprehensive Cancer Center, Columbia University Medical Center, New York, NY, USA. ${ }^{8}$ Department of Medicine, Columbia University Medical Center, New York, NY, USA.

Published online: 07 February 2022

\section{Reference}

1. Zhu, et al. Genome Med. 2019;11:69. https://doi.org/10.1186/s13073-0190685-z.

Ready to submit your research? Choose BMC and benefit from:

- fast, convenient online submission

- thorough peer review by experienced researchers in your field

- rapid publication on acceptance

- support for research data, including large and complex data types

- gold Open Access which fosters wider collaboration and increased citations

- maximum visibility for your research: over $100 \mathrm{M}$ website views per year

At $B M C$, research is always in progress.

Learn more biomedcentral.com/submissions

C The Author(s). 2022 Open Access This article is licensed under a Creative Commons Attribution 4.0 International License, which permits use, sharing, adaptation, distribution and reproduction in any medium or format, as long as you give appropriate credit to the original author(s) and the source, provide a link to the Creative Commons licence, and indicate if changes were made. The images or other third party material in this article are included in the article's Creative Commons licence, unless indicated otherwise in a credit line to the material. If material is not included in the article's Creative Commons licence and your intended use is not permitted by statutory regulation or exceeds the permitted use, you will need to obtain permission directly from the copyright holder. To view a copy of this licence, visit http://creativecommons.org/licenses/by/4.0/ The Creative Commons Public Domain Dedication waiver (http://creativecommons.org/publicdomain/zero/1.0/) applies to the data made available in this article, unless otherwise stated in a credit line to the data. 